\title{
Model Draft Regulation on Cryptocurrency in India
}

\author{
Rahul J. Nikam \\ Faculty of Law, Marwadi University, India. E-mail: rahul.nikam@marwadiuniversity.edu.in
}

\author{
ARTICLE INFO \\ Keywords: \\ Bitcoin; Cryptocurrency; \\ Cryptocurrency Business \\ Activity; Exchanges; \\ Intermediaries; RBI \\ regulations \\ How to cite: \\ Nikam, R.J. (2018). Model \\ Draft Regulation on \\ Cryptocurrency in India. \\ Hasanuddin Law Review, \\ 4(2): 146-161 \\ DOI: \\ 10.20956/halrev.v4i2.1466
}

\begin{abstract}
This article looks at the application of present Indian payment system policies and regulatory model on virtual-currency in India. In fact, simply banning cryptocurrency in India would not serve the purpose of legislature and Reserve Bank of India (RBI); rather it will boost cryptocurrency frauds in India due to absence of any law. The present article analysis shows that there is an ample scope within the present models and policies with necessary amendments to facilitate the regulation of virtual-currency in India. The analysis also suggests new model regulation on cryptocurrency which shall constitute the basic model regulations in India to govern cryptocurrency technology and products. Author uses the Banking Regulation Act as a model, regulating all types of new fintech products such as cryptocurrency, Bitcoin $\mathcal{E}$ business activity, its intermediaries, exchanges, customer protection in robust and transparent fashion in India.
\end{abstract}

Copyright $(2018$ HALREV. All rights reserved.

\section{Introduction}

The time has come to start thinking on future technological financial products and services that are growing rapidly in recent years. Some of these products and services are Cryptocurrency, virtual money and Bitcoin which are commonly known as electronic version of currency notes and coins. This new financial products and services are posing great challenges such as monetary and financial stability, protection of customers, costs and benefits of allowing these new forms in existing payment system before legislators and regulators. This has prompted other nations and India to see regulatory aspects that could be adopted to regulate virtual-currency, service providers in the form of intermediaries, exchanges, rights, duties, and liabilities in doing business and also protection to customer in payment system in India.

As law follows technology, crafting a new regulation of any new technology is a cumbersome task. It is the future that will answer, whether the virtual-currency will gain widespread acceptance and was it worth to spend public resources on a new technology. Nevertheless, this approach is also not good to buy as there are utmost chances that these types of new financial technological innovations, if allows to operate freeways may bring a significant problem to the existing financial system and 
ultimately the customers who will be the losers in the form of financial loss to them. However, in today's techno-savvy world, new techno-financial products and services are becoming necessity and getting central stage in financial transactions as a way of doing business transaction and creating a pool of money that brings much needed financial funds for the upcoming decade's developments.

With these backgrounds, Section 1 of the Article briefly explains what "cryptocurrency" (also known as Computer based algorithm mathematical based currencies) are and its operation in business. Section 2 is a Comparative Chart of selected countries across the world to understand the policy view and status of regulators on cryptocurrency regulations. Section 3 talks about some case laws related to Bitcoin pending before Court of law and some cases under police investigation. Section 4 is about the Policy and Circulars issued by RBI on the stand taken on virtual currency as of now and Central Government response in the form of setting up Committees for Policy directions. Section 5 is analysis of existing Indian Acts and regulatory schemes that could be brought to bear upon Cryptocurrency technology. This assessment of regulations also looks at various rationales for regulation for public law purposes such as Constitution of India, Banking Regulations Act, Foreign Exchange Management Act, Tax Law, Prevention of Money Laundering Act (PMLA), Know Your Customer (KYC) Norms, Securities Laws etc. and review existing regulation schemes in India. Section 6 discusses Model Draft Regulation on Cryptocurrency especially focusing on Uniform Regulation of Virtual-Currency Businesses Act.

Hence, some of the common primary framework such as few important definitions and key words are taken into consideration along with present RBI Guidelines to consolidates and suggest cryptocurrency regulation in India. In conclusion, offers some principles with the hope that will guide the development of new regulations for governs of cryptocurrency market in India and customer protection requirements coming out of cryptocurrency transactions.

\section{Cryptocurrency; Definition and Scope}

The term cryptocurrency is an intangible form of non-legal tender which can be used in place for legal tender ${ }^{1}$ and existed in electronic/ digital form used between online/Cryptocurrency members community. ${ }^{2}$ Virtual currencies are a subset of cryptocurrencies. "Bitcoin" is a subset of virtual-currency where value of a particular unit is validated through cryptography. virtual-currency generally requires consent of buyer and seller to a transaction. ${ }^{3}$ When a cryptocurrency is not backed by any precious metals but backed by government via giving "legal tender" status then such a cryptocurrency becomes fiat currency and not a "commodity-based currencies" or nonlegal tender currency which is simply a cryptocurrency. 4 Therefore fiat cryptocurrency status of cryptocurrency ${ }^{5}$ transaction would then fall back under the dominion of traditional money transfer regulation.

\footnotetext{
European Central Bank. (2012). Virtual Currency Scheme 2012 report. Retrieved from https://www.ecb.europa.eu/pub/pdf/other/virtualcurrencyschemes201210en.pdf

2 Hughes, S. J., \&Middlebrook, S. T. (2015). Advancing a Framework for Regulating Cryptocurrency Payments Intermediaries. Yale J. on Reg., 32, 495.

Velde, F. (2013). Bitcoin: A primer. Chicago Fed Letter, (Dec).

Ibid, p.3.

New York State Administrative Procedure Act (SAPA) 2015. 23 NYCRR Part 200 Virtual currencies.
} 
Cryptocurrency is also known as Bitcoin with virtual presence and unknown ownership maintained in a peer-to-peer network by entries in an enormous database called "block chain," and transactions takes place by participants keys known as crypto-credentials as a signature and validated by network i.e. signatures the transaction of sender and receiver being updated and reflected by block chain. This transaction is validated decentralized way by miners who maintain block chain. Some economist has termed Bitcoin as "fiduciary currency," because of no inherent value, and derive value in exchanges either from regular currency backed by government or accepted online by others.

In contemplating above situation, it seems logical before we think of regulating virtual currencies; we must understand what and when to regulate virtual currencies, which we are going to see subsequently in article.

\section{Overview of Selected Countries Regulations on Cryptocurrencies}

As virtual-currency market and transactions are sky rocking and these digital monies are non-legal tenders with different standards in most of the jurisdictions. Global regulators are divided on how to responses on it. As of now there is no international regulator to regulate virtual-currency. Following Chart shows there are two policy views on virtual-currency i.e., either it is legal tender or it is illegal, acts those are governing it and present policy status as of now (Table 1).

Table 1. Overview of Selected Countries Regulations on Cryptocurrencies

\begin{tabular}{|c|c|c|c|c|}
\hline No & Country & Policy & Acts & Status as of now 2018 \\
\hline 1 & Japan & $\begin{array}{l}\text { Legal only if Exchanges are } \\
\text { registered with the Japanese } \\
\text { Financial Services Agency. }\end{array}$ & $\begin{array}{l}\text { Payment Services Act } 2009 \\
\text { and Prevention of Transfer } \\
\text { of Criminal Proceeds Act } \\
\text { 2007(Amended) }\end{array}$ & $\begin{array}{l}\text { Legal tender as of last April } \\
2018 .\end{array}$ \\
\hline \multirow[t]{3}{*}{2} & \multirow[t]{3}{*}{ USA } & \multirow{2}{*}{$\begin{array}{l}\text { Definitions of Bitcoin \& other } \\
\text { cryptocurrencies are different as } \\
\text { per sectorial regulators in USA. }\end{array}$} & $\begin{array}{l}\text { FinCEN Regulations } \\
2014 / 2015\end{array}$ & $\begin{array}{l}\text { As per FinCEN -Not legal } \\
\text { tender. }\end{array}$ \\
\hline & & & $\begin{array}{l}\text { Uniform Regulation of } \\
\text { Virtual-Currency Business } \\
\text { Act (URVCBA)2017 }\end{array}$ & $\begin{array}{l}\text { As per CFTC-Bitcoin is a } \\
\text { commodity. }\end{array}$ \\
\hline & & & $\begin{array}{l}\text { Bank Secrecy Act (BSA)1970 } \\
\text { (FinCEN clarification) }\end{array}$ & $\begin{array}{l}\text { As per IRS- cryptocurrency } \\
\text { is not actually a currency \& } \\
\text { hope it will tax. }\end{array}$ \\
\hline 3 & $\begin{array}{l}\text { European } \\
\text { Union }\end{array}$ & $\begin{array}{l}\text { Legal, depending on the } \\
\text { country. } \\
\text { Regulations differ within the EU } \\
\text { bloc. }\end{array}$ & $\begin{array}{l}\text { VAT/GST and other taxes } \\
\text { applicable to transactions } \\
\text { made using Bitcoin for } \\
\text { goods and services. }\end{array}$ & $\begin{array}{l}\text { As per ECB -Member state } \\
\text { can't introduce its own } \\
\text { currency. } \\
\text {-France's \& Germany to } \\
\text { regulate the Bitcoin } \\
\text { Cryptocurrency market. }\end{array}$ \\
\hline 4 & $\begin{array}{c}\text { United } \\
\text { Kingdom }\end{array}$ & $\begin{array}{l}\text { Legal but must be register with } \\
\text { the Financial Conduct } \\
\text { Authority. }\end{array}$ & $\begin{array}{l}\text { Required to meet the same } \\
\text { anti-money-laundering } \\
\text { counter-terrorism standards } \\
\text { as other financial } \\
\text { institutions }\end{array}$ & $\begin{array}{l}\text { Not legal tender and } \\
\text { Sterling is the only legal } \\
\text { tender in the UK. }\end{array}$ \\
\hline 5 & $\begin{array}{l}\text { South } \\
\text { Korea }\end{array}$ & $\begin{array}{l}\text { Legal. Trading in virtual } \\
\text { currency by anonymous bank } \\
\text { accounts is banned. Need to } \\
\text { register with South Korea's } \\
\text { Financial Services Commission. }\end{array}$ & - & Not legal tender. \\
\hline 6 & China & $\begin{array}{l}\text { Illegal. Trading Bitcoin in China } \\
\text { is technically illegal. }\end{array}$ & - & Not legal tender. \\
\hline 7. & Singapore & $\begin{array}{l}\text { Legal. May come under purview } \\
\text { of the Monetary Authority of } \\
\text { Singapore. }\end{array}$ & - & Not legal tender. \\
\hline
\end{tabular}




\begin{tabular}{|c|c|c|c|c|}
\hline 8. & India & $\begin{array}{l}\text { Illegal. The Indian government } \\
\text { is planning to bring regulation. } \\
\text { RBI banned the sale or purchase } \\
\text { of cryptocurrency. }\end{array}$ & - & Not legal tender. \\
\hline 9. & Switzerland & $\begin{array}{l}\text { Legal, need to register with the } \\
\text { Swiss Financial Market } \\
\text { Supervisory Authority. }\end{array}$ & FINMA's Guidance 04/2017 & Legal. \\
\hline
\end{tabular}

Source: Secondary data, 2018 (edited).

\section{Overview and Application if any of Indian Acts on Cryptocurrency and Industry}

After going through aforementioned policy stand, let us see what are the laws may be applicable to cryptocurrency technology and its various products in India and understand whether Bitcoin falls under the review of Central Government.

\subsection{Constitution of India Act, RBI Act and FEMA}

Article 246 of Constitution along with Entry 36 and 46 of List I of the VII Schedule list out the subject matter to legislate currency, coinage, legal tender, foreign exchange and bills of exchange, cheques, promissory notes and other like instruments respectively by Center and State governments in India. Test is whether Bitcoin fulfill any condition of aforementioned instruments so Central government can legislate. Coming to the term of currency we need to understand the Reserve Bank of India (RBI) Act. Interestingly definition of currency is not defined by RBI Act rather it is defined by Foreign Exchange Management Act, 1999 (FEMA) stating in Section 2 (M) that "all currency notes, postal notes, postal orders, money orders, cheques, drafts, travelers' cheques, letters of credit, bills of exchange and promissory notes, credit cards or such other similar instruments, as may be notified by the Reserve Bank". Under the Currency Ordinance 1940, One rupee and Notes issued by RBI is defined as a legal tender and as far as Bitcoin is concerned since it is not legal tender thus falls out of this category. This analysis is also supported by Section 22 which enumerates the right of issuance of bank notes solely rest with RBI and bank notes are legal tender in India as per Section 26 of RBI Act. As per this analysis Bitcoin are not currency but having several features of a currency or legal tender thus qualify as "such other similar instruments" defined by Section 2(h) of RBI Act and to be notified by RBI. Thus, it is policy question before the RBI whether to recognize medium of certain electronic records claiming to be "Decentralized Digital Currency" or "Virtual Currency", such as, Bitcoin, litecoins, bbqcoins, and dogecoins etc. as such other similar instruments.

\subsection{Payment System Rules and Operating Standards in India}

S. 18 of the Payment System and Settlement Act (PSSA) $2007^{6}$ empowers RBI to regulate $^{7}$, supervise 8 and clear or settle payment among payer and beneficiary under the payment system 9 . Due to operational feature of peer-to-peer payment system of

\footnotetext{
Summers, B. J. (2012). Payment Systems: Design, governance and oversight: Central Banking Publ. Banking Regulation Act. 1949. S. 6(2). (Ind.) 
Bitcoin cannot clear or settle transaction thus cannot be treated as payment system ${ }^{10}$ under PSSA.

As per RBI directions, instrument ${ }^{11}$ carries the value stored in it and said value be paid by holder in transaction. In contrast, Bitcoin trade does not have these obligations while transacting and value of Bitcoin is speculative determined by market which keep fluctuate ${ }^{12}$ and fails to fulfill aforementioned criteria.

\subsection{RBI Pre-paid Payment Instruments Regulation ${ }^{13}$}

RBI has permitted three types of pre-paid payment instruments as Closed, Semi-closed and Open system payment instruments ${ }^{14}$. In contrast Bitcoin is generated by users through software and does not come under any category mentioned above. Aforementioned instruments value is up to INR 50,000 and validity is six months only from the date of issuance to the holder ${ }^{15}$. Therefore, those banks that complies these conditions can issue all three instruments. Non-Banking Financial Companies ("NBFC") and persons authorized by RBI can issue only semi-closed system payment instruments ${ }^{16}$. As Bitcoin is issued by software or server does not fit in the definition of person ${ }^{17}$ and thus cannot be consider under pre-paid instruments.

Further minimum Rs. 1 Crore capital adequacy compliance and RBI permission is required by any issuer and is allowed to issue pre-paid instruments. ${ }^{18} \mathrm{RBI}$ has allowed specific banks only to provide mobile based pre-paid payment instruments such as $\mathrm{m}$ wallet and m-accounts. ${ }^{19}$ This infers that even mobile app base bitcoins do not come under aforementioned regulations as they are not circulated by and lack permission from RBI.

10 Nakamoto, S. (2008). Bitcoin: A peer-to-peer electronic cash system.

11 Lewis, Nathan. (2014, March 06). Bitcoin Proves Friedman's Big Plan Was a Joke. Retrieved from https:/ / www.forbes.com/sites/nathanlewis/2014/03/06/ bitcoin-proves-friedmans-big-plan-was-ajoke/\#18c4b1757c91

12 RBI (2009). Guidelines for issuance and operation of Prepaid Payment Instruments in India. (Press Release: DGIPR/2009/1200). Retrieved from https://rbidocs.rbi.org.in/rdocs/Content/PDFs/DGIPR_1200.PDF

13 RBI (2014). All Prepaid Payment Instrument Issuers, System Providers, System Participants and all other Prospective Prepaid Payment Instrument Issuers. (Press Release: RBI/2014-2015/105 DPSS.CO.PD.PPI. No.3/02.14.006/2014-15) Retrieved from https://rbidocs.rbi.org.in/rdocs/notification/PDFs/116MCPPI 20062014FL.pdf

14 Ibid.

15 General Clauses Act. 1897. Section 3(42) "person" shall include any company or association or body of individuals, whether incorporated or not"."(Ind.)

16 RBI (2014). All Prepaid Payment Instrument Issuers, System Providers, System Participants and all other Prospective Prepaid Payment Instrument Issuers. (Press Release: RBI/2014-2015/105 DPSS.CO.PD.PPI.No.3/02.14.006/2014-15) Retrieved from https://rbidocs.rbi.org.in/rdocs/notification/ PDFs/116MCPPI20062014FL.pdf

17 Payment System and Settlement Act. 2007. S. 4 (Ind.)

18 RBI (2014). All Prepaid Payment Instrument Issuers, System Providers, System Participants and all other Prospective Prepaid Payment Instrument Issuers. (Press Release: RBI/2014-2015/105 DPSS.CO.PD. PPI.No.3/02.14.006/2014-15) Retrieved from: https://rbidocs.rbi.org.in/rdocs/notification/PDFs/ 116MCPPI20062014FL.pdf

19 RBI. (2014). Master Circular - Mobile Banking transactions in India - Operative Guidelines for Banks (Press release: RBI/DPSS/2014-15/104.(2014). Retrieved from: https://www.rbi.org.in/scripts/BS_ViewMas Circulardetails.asp $x$ ? $i d=8992$ 


\subsection{Deposit Taking and Deposit Insurance}

As per S. 5(b) of Banking Regulation Act, 1949 accepting deposits is a highly regulated business in the India. When bank is failed or unable to repay full amount of deposit, then up to Rs. 1 lakh is guaranteed to retrieve from the depositors' deposit, irrespective of the higher amount deposited by depositor in his account with bank. ${ }^{20}$ The amount hold in Cryptocurrency could be treated as deposits as represented virtually through technological advancement fail to fulfill condition of RBI as Bitcoin is not issued and hold by bank. Thus, above regulation do not cover the amount hold or represented by Bitcoin as it is non-legal currency and can be hold by non-bank entity.

\subsection{Anti-Money Laundering (AML) and Counter-Terrorism Financing}

Financial security is core concerned at international and national level at all time due to access and misused by criminals for various purposes. To curb these activities global enforcement agencies are working closely together. In India there is Prevention of Money Laundering Act (PMLA) 2002 \& PMLA Regulations, 2008 that has established mandatory ${ }^{21}$ on all authorized payment system operators and service providers to follow the know your customer guidelines 22 and report if there is any suspicious transaction to nodal agency called The Financial Intelligence Unit - India (FIU-India) ${ }^{23}$. In contrary to above, the structure of Bitcoin system bypasses this requirement and ensures to hide the identity of seller \& buyers. Hence Bitcoin system fails to comply above regulations which mandate customer information for opening \& operating account thus left the Bitcoin customer at vulnerable system to abuse and carrying out AML, KYC compliance becomes next to impossible.

\subsection{Remittance Transfers \& Cross Border Transfer of Bitcoin}

As per Liberalised Remittance Scheme (LRS) ${ }^{24}$ a sender in the India sends funds to a person located outside the India for those purpose only which are listed \& authorized by $\mathrm{RBI}^{25}$. This scheme is not available to the corporate, partnership firms, HUF, Trusts, etc. Coming to the Cross-border transfer of Bitcoin it is the FEMA that controls capital flows coming and moving out of India. As per S. $3^{26}$ of FEMA, only authorized persons are allowed to deal in or transfer any foreign exchange, security to any person under this section or permitted by RBI in this regard. ${ }^{27}$ Thus, inference can be drawn that there is no violation if resident Indian purchase Bitcoin from foreigner through

20 RBI Deposit Insurance and Credit Guarantee Corporation General Regulations. 1961. RBI Deposit Insurance System (DIS). (Ind.)

21 Prevention of Money Laundering Act. 2002. S. 18 read with S. 10(2)(Ind.)

22 RBI Direction on Know Your Customer (KYC) Direction, 2018 (updated).

23 Prevention of Money Laundering Act. 2002. S. 12(Ind.)

24 RBI. (2016). Master Direction - Liberalised Remittance Scheme (LRS) (Updated as on August 02, 2017) (RBI/FED/2017-18/3FED Master Direction No. 7/2015-16) Retrieved from: https://rbi.org.in/Scripts/NotificationUser.aspx?Id=10192EMode $=0$

25 RBI. (2016). Master Direction - Liberalised Remittance Scheme (LRS) -activities like account opining in foreign bank, purchasing property/ making investment abroad, setting up business abroad, loan to NRI, Private visits, Gift/donation, for employment in abroad, Emigration, Maintenance of close relatives abroad, Business trip, Medical treatment abroad and Studying abroad.

26 Foreign Exchange Management Act. 1999. Section 3 (i) make any payment to or for the credit of any person resident outside India in any manner; (ii) receive otherwise through an authorized person, any payment by order or on behalf of any person resident outside India in any manner; and (iii) enter into any financial transaction in India as consideration for or in association with acquisition or creation or transfer of a right to acquire, any asset outside India by any person. (Ind.)

27 Indian Constitution Act. 1950. Article 246. (Ind.) 
transferring money from legitimate bank channel to purchase Bitcoin. But it will be violation if resident Indian sales Bitcoin to foreigner and RBI can look into this aspect.

\subsection{Fraudulent E-banking Transaction and Limited Liability and Protection to Customer ${ }^{28}$}

Due to surge of customer grievances in online transactions customer protection has become the major concern. RBI has mandated to place in robust systems \& procedure dealing on safety \& security, risk management, detection and curbing of frauds so to make a customer feel safe \& secure in doing e-banking transaction. Also, RBI has frame guidelines to protect customers against the liabilities arising out of fraudulent ebanking transactions in the form of zero liability to limited liability on the financial institution based upon situations enumerated by RBI. The Bitcoin payment system is framed in such a manner where once transaction is initiated it cannot be reverted back and Bitcoin is permanently lost. Thus, customer is left at venerable situation and there is no central authority to report and take care of customer grievances.

\subsection{Securities Exchange Board of India (SEBI) Compliance Requirements and Cryptocurrency Broker-Dealer Registration}

One of the forms of regulating exchanges of Cryptocurrency is considering those people who facilitate exchanges of Cryptocurrency as a broker-dealer in share market. SEBI roles come in to picture when Cryptocurrency held separately for investment purposes or share dividend is being paid in the form of Cryptocurrency. Or brokerdealer are holding customer investment to be invested in share market is in the form of Cryptocurrency will requires to following SEBI Act 1992 \& Securities Contracts Regulations (SCRA) 1996. As SEBI (Stock-Brokers \& Sub-Brokers) Regulations $1992^{29}$ \& SEBI (Merchant Bankers) Regulations, 1992 (as amended in 2006) required to make sure of investor protection, rights \& liabilities of parties involve in transactions, dispute redressal mechanism for investors and all standard procedure and compliance requirements under PMLA Rules such as to maintain vigorous program of customer identification, anti-money laundering ${ }^{30}$ and economic sanctions. Thus, it can be infer that if Bitcoin exchanges want to give services of Bitcoin for investment purpose or share dividend then need to fall under the said regulations and need to comply with it.

\subsection{SEBI Regulations on Online Wallet Operators and Exchanges}

Online wallet payment and online Cryptocurrency exchanges for payment against security transaction in share market are not allowed in India. Recently SEBI has allowed to trade by way of instant access facility (IAF) through online mode and use of e-wallets for investment only in Mutual Funds (MFs) worth up to every year 50,000/or $90 \%$ of folio value, whichever is lower. Redemption of investments made through ewallet, however, can be done only through a bank account of the unit holder and into

28 RBI. (2017). Customer Protection - Limiting Liability of Customers in Unauthorized Electronic Banking Transactions. (RBI/2017-18/15 DBR.No.Leg.BC.78/09.07.005/2017-18).Retrieved from: https://rbidocs .rbi.org.in/rdocs/notification/PDFs/NOTI15D620D2C4D2CA4A33AABC928CA6204B19.PDF

29 SEBI (Stock-Brokers \& Sub-Brokers) Regulations. 1992. Regulations 3, 17, 18 \& 18A. (Ind.)

30 SEBI. (2008). Master Circular on Anti Money Laundering and Combating Financing of Terrorism (AML and CFT) Standard. (ISD/AML/CIR-1/2008).Retrieved from: https://www.sebi.gov.in/sebi_data/attachdocs/ 1332320892543.html 
the bank account of the investor. ${ }^{31}$ However, investment in MFs through the e-wallets is allowed subject to the condition that the said e-wallets are tie-ups with payments banks having RBI approval. ${ }^{32}$

This present regulation of RBI followed by SEBI can be extended to Cryptocurrency Ewallet operators and exchanges with objective to customer protection and are not exposed to higher credit and liquidity risks. Such a regulation will help to overcome from the situation where the customer suffered a loss due to failure of the Mt. Gox exchange in 2014 or aforementioned situations (emphasis added) on protection of the customer Bitcoin's and places security norms to be followed by Cryptocurrency market participants engaged in securities transactions including exchanges ${ }^{33}$ In furtherance of the SEBI jurisdiction is concerned, we need to examine important question i.e. whether Cryptocurrency is qualifying as "securities".

The way Cryptocurrency is functioning it cannot be treated as a security, but it does not mean that, it cannot be promoted as an investment option and utilized as a medium of exchanged commercially. If virtual currencies offered and consider as a security in the form of investment by investors then their promoters will fall under the jurisdiction of SEBI. But if promoter issues Cryptocurrency in the form of Initial Coin offerings (ICO) then promoters can offer and sale Cryptocurrency without triggering SEBI Regulations. Only the equity token, a subcategory of ICO can fall under the regulations of SEBI as these types of token are offered against representing ownership of an asset like debt or Company stock. Startups through block chain \& smart Contracts could issue tokens in the form of shares \& voting rights and can also raise debt in the form of token or coin from share markets. It is also interesting to note that this new method could be alternate and bypass to the SEBI Listing Obligations and Disclosure Requirements) (Amendment) Regulations, 2017. If we consider this form of Cryptocurrency as a security then it can be brought under the present SEBI regulations as nature of Cryptocurrency is raising fund from public in a same way Initial Public Offering (IPO) does. As it become imperative to SEBI to protect the investor, detail information about the product, risk associated with it and a wide array of remedies such as private rights, criminal \& civil actions that can be brought against them.

\subsection{Commodities Trading Regulation}

Most of the Countries have treated virtual currencies as a commodity and not foreign currencies. The idea of Cryptocurrency future contract is to provide a derivative to hedge risk for miners who then develop gradually other cryptocurrencies. If we consider this form of cryptocurrencies, future contract and trading are similar to the existing Commodity Derivatives Market Regulation of SEBI which focuses on market safety, efficiency, transparency and integrity and reducing cost of transaction, Risk Management System and various intermediaries and their Regulations. The definition of Commodity derivative as per S. 2 (bc) of SCRA is, its value, that is derived from

31 SEBI (2017). SEBI Board Meeting. (PR No.: 25/2017). Retrieved from: https://www.sebi.gov.in/media/pressreleases/apr-2017/sebi-board-meeting_34761.html

32 SEBI. (2017). Instant Access Facility and Use of e-wallet for investment in Mutual Funds. (SEBI/HO/IMD/DF2/CIR/P/2017/39). Retrieved from: https://www.sebi.gov.in/legal/circulars/may2017/instant-access-facility-and-use-of-e-wallet-for-investment-in-mutual-funds_34830.html

33 Hern, A. (2014). MtGox files for bankruptcy in Japan after collapse of Bitcoin exchange. The Guardian. Retrieved from: https://www.theguardian.com/technology/2014/feb/28/Bitcoin-mtgox-bankruptcy-japan 
prices or indices of prices of such underlying goods or activities, services, rights, interests and events in which contracts for future delivery are presently or in the future dealt in. As per section 44(D)(1)(c) of SCRA Securities Exchanges and Clearing Corporations Regulation (SECC) 2017 is triggered by the trading of a commodity. If trading is occurring or about to occur section $44(\mathrm{D})(1)(\mathrm{c})$ imposes obligations to regulate or control the business of buying, selling or dealing in commodity derivatives under the oversight of the Commodity Derivatives Market Regulation Department (CDMRD) of SEBI. As per the said SEBI regulation trading, clearing and settlement in market operation environment will not be seamlessly unless there is robust cyber security framework and compliance. Thus, with necessary amendment in present regulation, SEBI's CDMRD jurisdiction can be extended to cover the cryptocurrencies commodities trading. ${ }^{34}$ As SEBI present regulation on the Commodities market participants such as Commodity Derivatives Exchange, National Commodity Derivatives Exchange ${ }^{35}$ and "E-trading facility, audit ${ }^{36}$ and Investor Grievance Redressal system and arbitration mechanism are already in place as per SEBI CIR/CDMRD/DIECE/02/2015 circular.

\subsection{Taxation Law on Cryptocurrency}

Ministry of Finance through Department of Revenue has begun to regulate Cryptocurrency for taxation purposes. When we focused on "Income from Capital Gains (both short term and long term) and income from other sources" attracts the application of the Income Tax on trade in virtual currencies and gain out of it will be taxable. If you buy and sell cryptocurrencies frequently, the gains from such trading must be considered as income from trading when you file your Income Tax Return (ITR). If you do not trade in such currencies, the tax treatment may be different. Just as all other investment instruments, on more than three years investment taxed are charged as per a flat rate $20 \%$ with indexation benefits (inflation-adjusted) on Longterm capital gains. Moreover, investments less than three years should be considered as short-term capital gains and taxed as per your income tax slab.

Since the RBI is still to recognize these cryptocurrencies as a currency, they are neither legal nor illegal. The moment RBI declares it to be a currency; any trading in it will be subject to FEMA \& Regulations under it. It is just unclear if they should be considered as an asset as they are owned and owner earns profits from the increase in its value or should they be considered a long-term investment instrument. When Bitcoin is purchase for investment purpose it could be treated as capital asset as per S. 2 (14) of Tax Act, means any kind of property and every possible interest that can be acquire, hold or enjoy. If you buy and sell cryptocurrencies frequently, the gains from such trading must be considered as business income from trading when you file your

34 SEBI. (2016). Securities and Exchange Board of India (International Financial Services Centers) Guidelines, 2015 (IFSC Guidelines) - Inclusion of Commodity Derivatives. (CIR/MRD/DSA/41/2016). Retrieved from: https://www.sebi.gov.in/legal/circulars/mar-2016/securities-and-exchange-board-of-india-international-financialservices-centres-guidelines-2015-ifsc-guidelines-inclusion-of-commodity-derivatives_31906.html

35 SEBI. (2015). Comprehensive Risk Management Framework for National Commodity Derivatives Exchanges. (CIR/CDMRD/DRMP/01/2015). Retrieved from: https://www.sebi.gov.in/legal/circulars/oct2015/comprehensive-risk-management-framework-for-national-commodity-derivatives-exchanges_30784.html

36 SEBI. (2015). Annual System Audit, Business Continuity Plan (BCP) and Disaster Recovery (DR). (CIR/CDMRD/DEICE/01/2015). Retrieved from: https://www.sebi.gov.in/legal/circulars/nov-2015/annualsystem-audit-and-bcp-dr_31051.html 
income tax return (Form ITR 2). If selling of a Bitcoin is treated as business income treated as capital gain for tax purpose then it will be further classified as short-term or long-term. However, this classification will be depending on the period of holding of Bitcoin as mentioned in earlier.

Another issue is, does Bitcoin earned by mining process are taxable as business profits under capital asset. The difficulty here is that how to ascertain the cost of earning of Bitcoin from mining process to be classified as self-generated capital assets. Due to absence of Bitcoin acquisition cost, it results into failing of computation of capital gains thus no capital gains can be levied on transfer of such assets (as per Supreme Court judgment in the landmark case B. C. Srinivasan Setty, 1981) and Bitcoin earned by mining process may be exempt from tax. We also need to see the other issue associated with tax, is sale of Bitcoin by NRI on Indian exchanges and GST applicability on Bitcoin and Mining of it. The NRI sale of Bitcoin on Indian exchange is concerned, Bitcoin is intangible asset and income accruing from it is outside India and person is not residing in India. Therefore, it can't be taxed in India. Coming on Goods and Services Tax (GST) 2017 and Rules applicability is concerned, we need to answer first the policy question, is Bitcoin transaction is goods or service.

There are two views among the scholars; first view is Bitcoin could be considered as currency and if it so then it does not qualify for definition of goods, so no GST on Sale and Purchase of it. As per S.2 (52) the definition of goods in GST is every kind of movable Property other than Money and Securities. But if Bitcoin is not considered as a currency then GST on Sale and Purchase of Bitcoin will require paying. Logic behind it is, as per Rule 32 of Central GST Rules, when currency rate is not available, the value shall be $1 \%$ of gross amount of Indian rupees provided or received by the Person Changing the Money. Second view is Bitcoin could consider as service (trading in financial services and exchange), if so then GST at $12 \%$ to be charged as service charge by Exchanges and brokers for providing only service of sales and purchase of Bitcoin.

\section{Model Draft Regulation on Cryptocurrency in India}

The aim and objective of this regulation is to overcome from uncertainty on cryptocurrency technology and minimize the risk to individuals, to cryptocurrency businesses, and to government agencies. The Scope of Regulation is to govern the facilitation platform provided by centralize/decentralized Blockchain technology and service provider, transfer, exchange, and services of cryptocurrency and clearing houses on such platform. This facilitation is regulating the manner Licensure, Supervision, and user protections are affordable. They shall be treated as authorized person engaged in cryptocurrency business. The RBI Act and Banking Regulation Act will be superseding on this regulation and at all the time provisions of these Acts will also be applicable on person/ entity all the time.

There are some definitions which will help RBI to define and bring cryptocurrency under its jurisdiction. RBI has to take a policy decision on what to regulate i.e. is it a virtual currencies or Cryptocurrency Business Activity in India. We submit here that it will be prudent to control the medium of transaction and providers of cryptocurrencies transaction rather controlling cryptocurrency itself. This will help legislature to tailored assured, fair and predictable regulatory mechanism to cryptocurrency business and its intermediaries such as Broker, Bitcoin miners and Exchanges at par with traditional payment system and financial products in India. Accordingly, the propose regulation shall regulates Cryptocurrency business payment system with objective to provide 
Licenses, Procedures, Risk Management, Customer Protection and Dispute Redressal Mechanism on wherever possible in compliance with Banking Regulation Act, PMLA, terrorist funding activities and KYC norms.

The regulation shall be applicable to both forms of the Cryptocurrency that are control i.e. in centralized and decentralized form. ${ }^{37}$ Any regulation without defining the key words becomes futile in its governance. Therefore, following are some definitions which shall help in understanding and application of the proposed regulation.

Cryptocurrency/ virtual-currency means a digitized representation of unit of account or store value and is not a legal currency and denominated in legal currency, used as a medium of exchange; except a) in a transaction where value is merchant grants as a reward program, remains with merchant and can't be exchange against legal tender or bank credit $b$ ) digitized value used in online game issued by publisher of the game and used solely in the same game.

Let us see the definition of "Cryptocurrency and Cryptocurrency Business Activity" means: a) issuing or providing services or operating or administering in Cryptocurrency by way of control, holding, exchange, transfer, storing, directly or by agreement with service vender $b$ ) legal tender or bank credit converted in to digital representation outside the online game offered by publisher form which original digital representation of value was received.

To be covered by this regulation, the activity must involve "Cryptocurrency" and "Cryptocurrency Business Activity," as crucial definitions depends on key words and interpretation of control, exchange, store, and transfer. These active verbs application and definitions will help RBI to bring under its jurisdiction the Cryptocurrency activity as well as those who are engaged in this business will also be fall in line with the RBI mandates for doing banking related business in India. Word control can be defined as prevent indefinitely a virtual-currency transaction or authorized to execute unilaterally; word Exchange can be defined as a person authorized momentarily by the owner of Cryptocurrency to trade or convert for legal tender, bank credit, in other form of virtual currency. Word Store means authorized by owner of virtual currency to maintain control in the form of holding and taking deposits. Word Transfer means: crediting, moving or relinquish control of the Cryptocurrency from one account holder to another.

For assistance, let us understand how this four words works in defining Cryptocurrency business activity:

"Storage" of a Cryptocurrency means fund depositing with a bank in an electronicwallet or online form as a third-party Cryptocurrency business provider who act as an intermediate. This enables the owner to safely keep its currency in a safe deposit with the Cryptocurrency provider/ Storage Company who holds this currency on behalf of the owner of the Cryptocurrency and get some credentials. Owner sends the instruction to the storage company to transfer some Cryptocurrency to the seller against the purchase of the goods, services, or real estate from seller.

37 Uniform Law Commission. (2017). Uniform Regulation of Virtual-Currency Businesses Act. Retrieved from http://www.uniformlaws.org/Committee.aspx?title=Regulation\%20of\%20Virtual\% 20Currency\% 20Businesses $\% 20$ Act 
"Transfer" of a Cryptocurrency means transaction execution under ordinary systems of banking the way we transfer the money from one person to another person. The provider i.e. server running the distributed ledger which keeps and verifies of the computer code completes transfer transactions. The process is generally the amount and the computer code for specific amount is only known by the seller and buyer who direct the server of distributed ledger to transfer the coin against the transaction. Once server updates the completed transaction on ledger, that movement onward coin/ token belongs to seller. If buyer tries to sell/spend fraudulently same coin to others, server automatically detects and refuses, as buyer is no longer owner of that coin/token.

"Exchange" can understand the way we normally exchange the amount for purchase some good or food items in restaurant. Let assume you want to buy a pizza in restaurant with Bitcoin. Here you can easily transfer Bitcoin to the pizza restaurant in a direct P-to-B transaction where the server validates transaction on ledger, if valid, gets updated and reflects pizza restaurant as an owner of Bitcoin change of record of ownership is reflected on public ledger. The merchant gets its money and you get your pizza.

"Control" is the key factor in Bitcoin and these regulations, which decide the ownership as well as have an effect of the cyber security and fraud i.e. stealing of your Bitcoin private key. Here control is defined with the help of a product or service known in Bitcoin purchase and selling community as multiple signatures or better known as "multi sig." as it requires more than one key to authorize transaction. So another two key holders should also allow the said transaction, thus it provides must more security to the E-wallets while transacting. Nowadays, due to lot of frauds in Bitcoin transactions, Bitcoin networks are getting upgraded with much more complicated transaction that require the signatures of multiple people before the funds can be transferred known as M-of-N transactions. Thus, multiple people and software programs are involved and cooperation is required to do Bitcoin transaction.

License- The major condition is the server should be located in India so there is no problem of cross border jurisdiction. RBI is the final authority to issue license only after self-satisfying on the security, net worth, and reserves that need to be fulfilled by applicant. This is left for the RBI to finalize it. This regulation is not intended to derogate from any of RBI compliance requirements. This will help licensees to conduct operations and have sufficient funding available to wind up its operations due to unavoidable circumstances. This will also help RBI to keep check on licensees and protect the interest of customers in paying back their money. Renewal of license will be depending upon among other things are fully audited financial statement, compliance report, cyber security audit report and report of resolution of customer grievances. The license is not assignable or transferable to anyone. At any point of time if licensee wishes to allow merging with, consolidate with, or acquire another business which result in change in control need prior approval of RBI and RBI decision shall be final and binding on licensee. This condition will help to minimize the risk and frauds. RBI will issue different licenses to the exchanges, custodian and brokers with different conditions and norms keeping in mind the requirement of the volume of business carried by each of these entities. 
Real time Centralized Transaction Repository (RCTR) and RBI Vigilance Department- RBI shall be having its own real time centralized transaction repository and all licensees shall be required to keep all real time transaction information and KYC information relating to each transaction linked with this repository. Thus, RBI will be having control on all the transactions and KYC information relating to such transactions which shall help RBI to have real time vigilance \& tampered free record of each transaction. RBI will have vigilance department to control and vigilance on suspicious transaction, money laundering and terrorist funding activity which might be taking place.

Examination- Power to examine records, data inspection and compliance of norms is rest with RBI. Licensee is required to maintain the KYC Norms of transaction holder and complete information as per AML Act including date, time and instruction given by transaction holder for next five years. Total number of transactions taken place in financial year, aggregate number of transaction form of virtual currency into legal tender or other types of cryptocurrency, complete audit report comprising assets, liability, capital and expenditure of licensee, report of resolution of customer grievances, Book of Registry containing all transaction \& customer information, reporting of suspicious transactions Book and action taken against such transactions, report of fail transactions and reason of it and any other information desired by RBI. The Bankers Books Evidence Act, 1891 will be applicable on licensee under this regulation. Licensee is bound to cooperate, coordinate, consult, and share records and other information with the other central regulatory agencies along with RBI.

Enforcement- facilitation of cryptocurrency business shall be taking place only after permission of RBI otherwise it will treat as illegal business. The offence related to cryptocurrency will be treated as banking fraud and shall be treated at par and with same provisions of existing civil and criminal laws which are applicable to banking frauds. RBI may take administrative action in the form of suspend or revoke a license, restraint licensee to participate in business, impose penalty, recovers money from security deposit, conditional approval to do business, appoint RBI Administrator as care taker, take appropriate recourse through court of law etc. There shall be applications of other laws wherever it is appropriate such as Bankruptcy and Insolvency Act, Company Act, SARFAESI Act, AML Act, PSSA, FEMA etc. Civil penalties shall be the equivalent amount of fraud or three times the amount of profits made out of cryptocurrency trading, whichever is higher and/or may declared as willful defaulter by RBI in case licensee absconded from India. The criminal penalties shall be imprisonment up to five year and lifelong banned on licensee.

\section{Conclusion}

Increasing popularity and involvement of more Indian in cryptocurrency trading, it is high time for India to take a firm decision on Cryptocurrency trading and bring regulation to regulate it. The regulation is talking about regulating the technological platform models that are being used by cryptocurrency and intermediary while facilitating various services. Whether cryptocurrency be treated as a legal tender and allowed to exchange against fiat currency is the policy decision and is left out for the RBI and Central Government to decide. RBI should not treat Cryptocurrency industry as a problem to the Banking system keeping in mind that it is having a valuable innovative technological solution and its potential applications to the banking system. 
Rather RBI must explore how to harness Distributed Ledger Technology (DLT) for Financial Services and overall benefit to the economy in India. The application of Blockchain in trading, financing, lending and other financial services will be opening a new era of fintech products \& services in Indian economy. Thus, this technologically innovative platform i.e. centralized or decentralized distributed ledger is having potential to improve the efficiency and inclusiveness of the financial system in India. Cryptocurrency platform will boost up society which is digitally empowered, boost up to the digital India Program and knowledge economy.

This move will be a thrust to ensuring E-Governance covering electronic services in banking industry, user friendly products, devices, job opportunities to the youngster and overall inclusive growth of Indian economy. This payment ledger system is opportunity for India to overcome barriers of socio-economical in society and give wide financial access.

\section{References}

Atzori, M. (2015). Blockchain technology and decentralized governance: Is the state still necessary?. Available at SSRN: https://ssrn.com/abstract $=2709713$ or http://dx.doi.org/10.2139/ssrn.2709713

Bitcoin Rs 2,000 Crore Fraud: Amit Bhardwaj arrested at Delhi Airport for cheating 8,000 people. (2018, April 06). Financial Express. Retrieved from https://www.financialexpress.com/market/Bitcoin-fraud-in-india-man-arrested-forduping-8000-people-in-rs-2000-crore-Cryptocurrency-scam/1122575/

Bossone, B., \& Cirasino, M. (2001). The oversight of the payments systems: a framework for the development and governance of payment systems in emerging economies: The World Bank.

Das, S. (2016, December 05). First Reported Case of Fraud Involving Bitcoin, says Indian City's Police. CCN. Retrieved from: $h t t p s: / / w w w . c c n . c o m / f i r s t-r e p o r t e d-f r a u d-$ case-involving-Bitcoin-says-indian-citys-police/

European Central Bank. (2012). Virtual Currency Scheme 2012 report. Retrieved from: https://www.ecb.europa.eu/pub/pdf/other/virtualcurrencyschemes201210en.pdf

Hern, A. (2014. February 14). MtGox files for bankruptcy in Japan after collapse of Bitcoin exchange. The Guardian. Retrieved from https://www.theguardian.com/technology/2014/feb/28/Bitcoin-mtgox-bankruptcy-japan

Hughes, S. J., \& Middle brook, S. T. (2015). Advancing a Framework for Regulating Cryptocurrency Payments Intermediaries. Yale J. on Reg., 32, 495.

Indian Constitution Act. 1950. Article 246. (Ind.)

Kaplanov, N. (2012). Nerdy money: Bitcoin, the private digital currency, and the case against its regulation. Loy. Consumer L. Rev., 25, 111.

Kashyap, Nitisha. (2018, April 21). Inspired by Pune's Bitcoin Scam, Haryana Duo Dupe Nearly 5,000 People in Delhi; Arrested. CNN-News18. Retrieved from https://www.news18.com/news/india/inspired-by-punes-bitcoin-scam-haryana-duo-dupenearly-5000-people-in-delhi-arrested-1725259.html

Lewis, Nathan. (2014, March 06). Bitcoin Proves Friedman's Big Plan Was a Joke. Retrieved from https://www.forbes.com/sites/nathanlewis/2014/03/06/bitcoin-provesfriedmans-big-plan-was-a-joke/\#18c4b1757c91 
Ministry of Finance (2017). Government Cautions People Against Risks in Investing in Virtual 'Currencies'; Says VCs are like Ponzi Schemes. (Release ID: 1514568). Press Information Bureau, Government of India, Delhi. Retrieved from http://pib.nic.in/newsite/PrintRelease.aspx?relid $=174985$

Ministry of Finance (2017). Government constitutes an Inter- Disciplinary Committee chaired by Special Secretary (Economic Affairs) to examine the existing framework with regard to Virtual Currencies. (Release ID: 16092)Press Information Bureau, Government of India, Delhi. Retrieved from http://pib.nic.in/newsite/ PrintRelease.aspx?relid $=160923$

New York State Administrative Procedure Act (SAPA) 2015. 23 NYCRR Part 200 Virtual currencies.

Prevention of Money Laundering Act. 2002. S. 18 read with S. 10(2)(Ind.)

Public Uniform Law Commission. (2017). Uniform Regulation of Virtual-Currency Businesses Act.

Publications of Ministries - Parliament of India, Lok Sabha (2017). Unstarred Question No: 100 on Status of Cryptocurrencies. Retrieved from

RBI Deposit Insurance and Credit Guarantee Corporation General Regulations. 1961. RBI Deposit Insurance System (DIS). (Ind.)

RBI Direction on Know Your Customer (KYC) Direction, 2018 (updated). Retrieved from https:// www.rbi.org.in/ scripts/ NotificationUser.aspx?Id=10292\&Mode=0

RBI. (2009). Guidelines for issuance and operation of Prepaid Payment Instruments in India. (Press Release: DGIPR/2009/1200). Retrieved from: https://rbidocs.rbi.org.in/rdocs/Content/PDFs/DGIPR_1200.PDF

RBI. (2013). Cautions users of Virtual Currencies against Risks.(Press Release: 20132014/1261). RBI Department of Communication, Mumbai. Retrieved from https://rbidocs.rbi.org.in/rdocs/PressRelease/PDFs/IEPR1261VC1213.PDF

RBI. (2013). Master Circular - Know Your Customer (KYC) norms / Anti-Money Laundering (AML)standards/Combating of Financing of Terrorism (CFT)/Obligation of banks under PMLA, 2002. Retrieved from https://www.rbi.org.in/scripts/BS_ViewMas Circulardetails.aspx?id $=8179$

RBI. (2014). All Prepaid Payment Instrument Issuers, System Providers, System Participants and all other Prospective Prepaid Payment Instrument Issuers.(Press Release: RBI/2014-2015/105 DPSS.CO.PD.PPI.No.3/02.14.006/2014-15) Retrieved from https://rbidocs.rbi.org.in/rdocs/notification/PDFs/116MCPPI20062014FL.pdf

RBI. (2014). Master Circular - Mobile Banking transactions in India - Operative Guidelines for Banks (Press release: RBI/DPSS/2014-15/104.(2014). Retrieved from https://www.rbi.org.in/scripts/BS_ViewMasCirculardetails.aspx?id=8992

RBI. (2016). Master Direction - Liberalised Remittance Scheme (LRS) (Updated as on August 02, 2017) (RBI/FED/2017-18/3FED Master Direction No. 7/2015-16) Retrieved from $h$ ttps://rbi.org.in/Scripts/NotificationUser.aspx?Id=10192EMode $=0$

RBI. (2017). Cautions regarding risk of virtual currencies including Bitcoins. (Press Release: 2017-2018/1530). RBI Department of Communication, Mumbai. Retrieved from https://rbidocs.rbi.org.in/rdocs/PressRelease/PDFs/PR15304814BE14A3414FD490B47B OB1BF79DDC.PDF

RBI. (2017). Customer Protection - Limiting Liability of Customers in Unauthorized Electronic Banking Transactions. (RBI/2017-18/15DBR.No.Leg.BC.78/09.07. 005/2017-18). Retrieved from https://rbidocs.rbi.org.in/rdocs/notification/PDFs/ NOTI15D620D2C4D2CA4A33AABC928CA6204B19.PDF 
RBI. (2017). Master Direction - Money Transfer Service Scheme (MTSS.)(RBI/FED/201617/52 FEDMaster Direction No.1/2016-17). Retrieved from: https:// www.rbi.org.in/scripts/NotificationUser.aspx $? I d=10868 \mathcal{E} f n=5 \mathcal{E} M$ ode $=0$

RBI. (2017). Master Direction on Issuance and Operation of Prepaid Payment Instruments (Updated as on December 29, 2017).(RBI/DPSS/2017-18/58Master DirectionDPSS.CO.PD.No.1164/02.14.006/2017-18). Retrieved from https://rbi.org.in/scripts/BS_ViewMasDirections.aspx?id=11142

RBI. (2017). Master Direction on Issuance and Operation of Prepaid Payment Instruments. RBI/DPSS/2017-18/58. (2017). Retrieved from https://rbi.org.in/scripts/BS_ ViewMasDirections.aspx?id $=11142$

RBI. (2018) Prohibition on dealing in Virtual Currencies. (circular No.DBR.No.BP.BC.104/ 08.13.102/201718 dated 06.04.2018). RBI Department of Communication, Mumbai. Retrieved from https://rbidocs.rbi.org.in/rdocs/notification/PDFs/ NOTI15465B741A10B0E45E896C62A9C83AB938F.PDF

SEBI (Stock-Brokers \& Sub-Brokers) Regulations. 1992. Regulations 3, 17, 18 \& 18A. (Ind.)

SEBI. (2008). Master Circular on Anti Money Laundering and Combating Financing of Terrorism (AMLand CFT) Standard. (ISD/AML/CIR-1/2008).Retrieved from https://www.sebi.gov.in/sebi_data/attachdocs/1332320892543.html

SEBI. (2015). Annual System Audit, Business Continuity Plan (BCP) and Disaster Recovery (DR).(CIR/CDMRD/DEICE/01/2015).Retrieved from https://www.sebi.gov.in/ legal/circulars/nov-2015/annual-system-audit-and-bcp-dr_31051.html

SEBI. (2015). Comprehensive Risk Management Framework for National Commodity Derivatives Exchanges. (CIR/CDMRD/DRMP/01/2015).Retrieved from https://www.sebi.gov.in/legal/circulars/oct-2015/comprehensive-risk-managementframework-for-national-commodity-derivatives-exchanges_30784.html

SEBI. (2017). Instant Access Facility and Use of e-wallet for investment in Mutual Funds. (SEBI/HO/IMD/DF2/CIR/P/2017/39). Retrieved from https://www.sebi.gov.in/legal/circulars/may-2017/instant-access-facility-and-use-of-ewallet-for-investment-in-mutual-funds_34830.html

SEBI. (2017). SEBI Board Meeting. (PR No.:25/2017). Retrieved from https://www.sebi.gov.in/media/press-releases/apr-2017/sebi-board-meeting_34761.html

Shaikh, Z. S. (2018, April 08). Coin secure claims loss of Bitcoins worth Rs19 crore. Live Mint. Retrieved from https://www.livemint.com/Money/tIphcc6QGYd0g5JEDjGMcO/ Indias-Coinsecure-exchange-says-3-million-worth-of-Bitcoin.html

Siddharth Dalmia \& Anr. Vs. Union of India E Ors. (2017) Supreme Court of India Record of Proceedings. Retrieved from https://supremecourtofindia.nic.in/ supremecourt/2017/34785/34785_2017_Order_17-May-2018.pdf

Summers, B. J. (2012). Payment systems: design, governance and oversight: Central Banking. Transmitter laws. NC Banking Inst., 18, 529.

Tsukerman, M. (2015). The block is hot: A survey of the state of Bitcoin regulation and suggestions for the future. Berkeley Tech. LJ, 30, 1127. 